LAPORAN KASUS

\title{
Penanganan Inkompatibilitas Darah pada Wanita Hamil yang Menderita Lupus Eritematosus Sistemik
}

\section{Blood Incompatibility Management in a Pregnant Woman with Systemic Lupus Erythematous}

\author{
Maulydia $^{凶}$, H.R. Eddy Rahardjo \\ Departemen Anestesiologi dan Reanimasi, Fakultas Kedokteran, Universitas Airlangga/RSUD \\ Dr. Soetomo, Surabaya, Indonesia \\ ${ }^{\bowtie}$ Korespondensi: maulydia@ @k.unair.ac.id
}

\begin{abstract}
Background: Systemic lupus erythematous (SLE) is an autoimmune disease which is characterized by the antibodies production against the cell's nucleus. Pregnancy in a SLE woman is associated with an increase rate of adverse outcome. The frequency of pregnancy lost on SLE in general US population decreased from 43\% (1960-1965) to 17\% (2000-2003). Dr. Soetomo Hospital Surabaya reported 166 women with SLE during Mei 2003-April 2004. Statistically there are 1-2/2000 pregnancies with SLE cases.

Cases: A 25-year-old 4-week pregnant woman came to the emergency room because she had fluxes. She was diagnosed with SLE and lupus nephritis since 2003. The obstetric ultrasound showed a death conception (IUFD). She was routinely consumed methylprednisolone, lansoprazole, folic acid, and sandimun to treat her SLE. Her laboratory result showed hemoglobin 5,2 gr/dl, platelet 146.000, albumin 1,56 g/dl, and increase of APTT. She was planned to have blood and albumin transfusions. On the next day, she had miscarriage with retained placenta in her uterine. Her laboratory findings showed a significant decreased in hemoglobin level 3,7 gram/dl. Blood transfusion had to be delayed due to the cross test incompatibility with 20 bags of donor blood. As an alternative, we decided to give her a bag of washed erythrocyte transfusion with major cross match threshold <3. Finally, her hemoglobin rose to $6.3 \mathrm{~g} / \mathrm{dl}$ and the placenta came out spontaneously.
\end{abstract}

Discussion: The aborted pregnancy in this patient was caused either by SLE during pregnancy or it's medication. SLE during pregnancy is correlated with higher incidence of anemia. Severe anemia in this patient needed to be transfused immediately, but due to the hemolytic anemia related to SLE, her cross test results were incompatible. Intravenous Immunoglobulin (IVIG) was not an option in this patient due to economic reason. Finally, washed erythrocyte with major cross match $<3$ were chosen as the alternative treatment for anemia in this patient.

Conclusion: SLE in pregnancy may cause abortion and severe anemia, so a blood transfusion with washed erythrocyte could be a good alternative to treat anemia. 
Keywords: anemia; blood transfusion; incompatibility; pregnancy; systemic lupus erythematous

\begin{abstract}
ABSTRAK
Latar Belakang: Lupus eritematosus sistemik (LES) adalah salah satu penyakit autoimun yang ditandai dengan produksi antibodi terhadap komponen-komponen inti sel. Kehamilan pada wanita dengan LES dihubungkan dengan meningkatnya risiko bagi ibu dan bayi. Frekuensi kegagalan kehamilan di Amerika Serikat didapat sebesar 43\% pada tahun 1960-1965 dan berkurang menjadi 17\% pada tahun 2000-2003. RSUD Dr. Soetomo mendapatkan 166 penderita wanita dengan LES di dalam satu tahun (Mei 2003-April 2004). Dari setiap 2000 penderita, ditemukan 1-2 kasus dengan LES.

Kasus: Seorang wanita berusia 25 tahun, dengan usia kehamilan 4 minggu datang ke instalasi gawat darurat (IGD) karena adanya perdarahan dari jalan lahir. Dia diketahui mengidap LES dan lupus nefritis sejak tahun 2003. Hasil ultrasonografi (USG) kandungan menunjukkan adanya kematian hasil konsepsi (IUFD). Obat yang rutin diminum adalah metilprednisolon, lansoprazole, asam folat, dan sandimun. Pada pemeriksaan lab didapatkan hemoglobin 5,2 gr/dl, platelet 146.000, albumin 1,56 dan peningkatan APTT. Pasien direncanakan untuk transfusi darah dan albumin. Keesokan harinya, pasien mengalami keguguran dengan plasenta tertinggal disertai dengan penurunan hb menjadi 3,7 gr/dl. Transfusi tertunda oleh karena adanya inkompatibilitas dengan 20 kantung darah. Akhirnya diputuskan untuk melakukan transfusi menggunakan 1 kantung washed erithrocyte dengan major cross match threshold $<3$. Pada akhirnya $\mathrm{Hb}$ berhasil naik menjadi $6.3 \mathrm{~g} / \mathrm{dl}$ dan plasenta dapat keluar secara spontan.

Pembahasan: Terjadinya abortus pada pasien ini dapat disebabkan oleh kehamilan sebelum remisi LES, maupun pengobatan untuk LES yang rutin dikonsumsi. Pada pasien LES yang mengandung, didapatkan peningkatan angka kejadian anemia. Anemia pada pasien ini membutuhkan tranfusi segera, namun karena pada pasien LES yang seringkali mengalami anemia hemolitik, tranfusi tertunda karena hasil cross test yang inkompatible. Keterbatasan biaya menyebabkan pemberian intravenous immunoglobuline tidak dapat dilakukan. Pada akhirnya, tranfusi menggunakan washed erithrocyte dengan major cross match $<3$ dapat menjadi alternatif pilihan.

Kesimpulan: Kehamilan dengan LES dapat sebabkan terjadinya abortus dan anemia berat, sehingga tranfusi menggunakan washed erithrocyte dapat menjadi alternatif terapi yang baik.
\end{abstract}

Kata Kunci: anemia; inkompabilitas; kehamilan; lupus eritematosus sistemik; tranfusi darah 


\section{PENDAHULUAN}

Lupus eritematosus sistemik (LES) adalah penyakit auto-imun kompleks, yang ditandai dengan adanya autoantibodi terhadap inti sel. ${ }^{1}$ Penyakit ini melibatkan banyak sistem organ dalam tubuh. Penyebab LES belumlah diketahui dengan pasti, namun diperkirakan melibatkan interaksi yang kompleks dan multifaktorial antara variasi genetik dan faktor lingkungan. ${ }^{2}$ LES ditemukan lebih banyak pada wanita dibandingkan laki-laki, dengan rasio 5:1. Penyakit ini juga memiliki prevalensi yang lebih tinggi pada wanita dengan usia produktif (15-40 tahun). ${ }^{3}$

Insiden LES di Amerika Serikat berkisar 52 kasus per 100.000 penduduk. ${ }^{1}$ Di Indonesia, belum semua wilayah mempunyai data tentang insiden LES. Dari RSUP Cipto Mangunkusumo (RSCM) Jakarta, didapatkan 1,4\% kasus LES dari total kunjungan pasien di poliklinik reumatologi penyakit dalam pada tahun 2002. Di RSUP Dr. Hasan Sadikin Bandung, di dapatkan 291 pasien SLE atau 10,5\% dari total pasien yang berobat ke poklinik reumatologi selama tahun 2010. ${ }^{1}$ Data di RSUD Dr. Soetomo Surabaya melaporkan bahwa terdapat 166 penderita wanita dengan SLE pada Mei 2003 - April 2004, dengan insiden kehamilan dengan lupus sebesar 1-2 kasus tiap 2000 kehamilan. ${ }^{4}$

Kehamilan pada seorang wanita penderita LES berhubungan dengan peningkatan risiko yang membahayakan bagi ibu dan bayi yang dikandung. Data di Amerika Serikat menyebutkan frekuensi keguguran pada wanita dengan LES mencapai $43 \%$ pada tahun 1960-
1965, dan terus berkurang hingga 17\% pada tahun 2000-2003. Berdasarkan pada 29 studi observasional pada 2751 kehamilan di tahun 2010, didapatkan $16 \%$ kejadian abortus spontan dan $12,7 \%$ kejadian intrauterine growth restriction. ${ }^{5}$

\section{KASUS}

Anamnesa

Seorang wanita berusia 25 tahun, dengan usia kehamilan 4 minggu datang ke IGD RSUD Dr. Soetomo karena perdarahan dari jalan lahir. Wanita ini didiagnosa menderita LES sejak 2013, dan rutin kontrol di poli reumatologi penyakit dalam RSUD Dr. Soetomo. Pasien terakhir kali memeriksakan diri untuk LES 4 bulan sebelum masuk rumah sakit. Pasien mendapat terapi berupa: metil-prednisolon tablet oral $8 \mathrm{mg}$ tiap 8 jam, Lansoprazole 1 tablet oral tiap 24 jam, asam folat tablet oral 1000 mcg tiap 24 jam, dan sandimun tablet oral $50 \mathrm{~g}$ tiap 12 jam.

\section{Pemeriksaan fisik}

Pada pemeriksaan tanda vital didapatkan: tekanan darah 116/81 $\mathrm{mmHg}$, nadi $95 \mathrm{x} / \mathrm{menit}$, respirasi 20 $\mathrm{x} /$ menit, dan temperatur $37,4^{\circ} \mathrm{C}$. Tidak ditemukan adanya edema, namun dari pemeriksaan vagina, ditemukan adanya fluksus. Satu hari setelah masuk rumah sakit, penderita mengalami keguguran, tetapi plasenta masih berada di dalam rahim.

Pemeriksaan penunjang

Pemeriksaan laboratorium segera saat penderita masuk ke IGD menunjukkan hasil sebagai berikut: 
Tabel 1. Hasil pemeriksaan laboratorium saat masuk IGD

\begin{tabular}{lllllc}
\hline \multicolumn{2}{c}{ Darah Lengkap } & \multicolumn{2}{c}{ Kimia Klinik } & \multicolumn{2}{c}{ BGA } \\
\hline Hb & 5,2 & GDA & 106 & PH & 7,5 \\
WBC & 9.470 & BUN/SK & $22 / 0,8$ & PCO2 & 23,7 \\
$\mathrm{PLT}$ & 146.000 & AIb & 1,56 & HCO3 & 18,7 \\
$\mathrm{Hct}$ & 12,70 & SGOT/SGPT & $23 / 14$ & $\mathrm{BE}$ & $-4,7$ \\
& & Na/K/CI & $140 / 4,1 / 116$ & $\mathrm{SO} 2$ & 98,2 \\
& & PPT & $11,8(11)$ & & Urin Lengkap \\
& & APTT & $38,4(24)$ & Prot & +3 \\
& & Ca & 6,8 & Elitrosit & $20-25$ \\
& & Bil D/T & $0,38 / 1,29$ & Lekosit & $0-2$ \\
& & LED & 2 & Epitel & Sedikit \\
\hline
\end{tabular}

Pada pemeriksaan USG sesaat setelah penderita tiba, menunjukkan bahwa janin sudah meninggal (IUFD). Hasil pemeriksaan laboratorium ulang setelah bayi dinyatakan meninggal/ keguguran memperlihatkan adanya anemia berat, seperti pada Tabel 2 .
Pasien direncanakan untuk transfusi darah, sehingga perlu dilakukan crosstest untuk mencari darah yang sesuai. Adapun hasil cross-test dari bank darah menunjukkan inkompatibilitas pada 40 kantung darah, seperti yang nampak pada Tabel 3.

Tabel 2. Hasil pemeriksaan laboratorium ulangan setelah keguguran

\begin{tabular}{cccccc}
\hline \multicolumn{2}{c}{ Darah Lengkap } & \multicolumn{2}{c}{ Kimia Klinik } & \multicolumn{2}{c}{ BGA } \\
\hline Hb & 3,7 & AIb & 1,72 & Prot & +3 \\
WBC & 10.600 & SI & $37(35-150)$ & Elitrosit & $10-15 / \mathrm{lp}$ \\
PLT & 153.000 & TIBC & $127(250-450)$ & Lekosit & $10-15 / 1 \mathrm{p}$ \\
Hct & 12 & BT & $1^{\prime} 30$ ' (N) & Epitel & Sedang \\
& & CT & 4' (N) & & \\
\hline
\end{tabular}

Tabel 3. Hasil pemeriksaan cross-test

\begin{tabular}{crc}
\hline NO & $\begin{array}{c}\text { Nomor } \\
\text { Kantong }\end{array}$ & $\begin{array}{c}\text { Hasil } \\
\text { Pemeriksaan }\end{array}$ \\
\hline 1 & 170580761 & $3+5$ \\
2 & 170580771 & $3+5$ \\
3 & 170564611 & $3+5$ \\
4 & 170587031 & $3+5$ \\
5 & 170586791 & $3+5$ \\
6 & 170565241 & $3+$ \\
7 & 170531421 & $3+$ \\
8 & 170502101 & $3+$ \\
9 & 170502111 & $3+$ \\
10 & 170502071 & $3+$ \\
\hline
\end{tabular}

\begin{tabular}{llc}
\hline No & $\begin{array}{c}\text { Nomor } \\
\text { Kantong }\end{array}$ & $\begin{array}{c}\text { Hasil } \\
\text { Pemeriksaan }\end{array}$ \\
\hline 11 & 170502091 & $3+$ \\
12 & 170542051 & 35 \\
13 & 170531411 & $3+5$ \\
14 & 170448791 & $3+$ \\
15 & 170448821 & $3+$ \\
16 & 170448811 & $3+$ \\
17 & 170502081 & $3+$ \\
18 & 170542091 & $3+5$ \\
19 & 170448831 & $3+$ \\
20 & 170542571 & $3+$ \\
\hline
\end{tabular}

\section{Pengelolaan di Ruang Observasi Intensif}

Oleh karena sukarnya mendapatkan kantung darah yang sesuai untuk melakukan transfusi, diputuskan untuk

melakukan tranfusi dengan washed erythrocyte, dengan treshold major cross match $<3$. Setelah pemberian 1 kantung, hemoglobin penderita naik menjadi 6,3 dan tidak didapatkan adanya komplikasi 
transfusi pada penderita. Oleh karena itu, kemudian diputuskan untuk diberikan transfusi 1 kantung washed erytrocite lagi. Selama perawatan, plasenta berhasil keluar secara spontan, sehingga tindakan kuretase yang semula direncanakan, akhirnya dibatalkan.

\section{PEMBAHASAN}

Tidak ada data yang dapat dipercaya tentang riwayat pengobatan LES pada pasien ini. Kehamilan yang terjadi pada pasien LES yang belum mengalami remisi, memiliki risiko untuk mengalami kematian janin sebesar 50-75\%, dengan angka kematian ibu sebesar $10 \% .^{6}$ Risiko terjadinya eksaserbasi pada periode awal kehamilan (trimester I) seperti pada pasien ini (4 minggu) adalah sebesar 13\%.7 Pengobatan intensif dengan prednisolon juga berhubungan dengan terjadinya berat bada lahir rendah (BBLR). ${ }^{5}$ Kejadian IUFD pada pasien LES, dapat diakibatkan oleh perjalanan penyakit maupun karena obat-obatan yang diminum penderita untuk mengurangi risiko terjadinya flare. Abortus spontan pada kehamilan dengan LES dapat terjadi dengan atau tanpa ditemukannya antibodi anti-fosfolipid. ${ }^{5}$ LES dalam kondisi aktif dan adanya lupus nefritis meningkatkan risiko kematian janin. Adanya proteinuria, hipertensi, trombositopenia, dan antibodi antifosfolipid merupakan prediktor negatif terhadap kelangsungan hidup janin. $^{8}$

Komplikasi selama kehamilan meningkat 2-4 kali lebih tinggi pada wanita penderita LES. Salah satunya ialah komplikasi hematologi, di mana kejadian anemia ditemukan pada lebih dari $12 \%$ kehamilan dengan LES. Kondisi ini sering kali baru ditemukan pada saat persalinan. ${ }^{9}$ Selain anemia, angka kejadian trombositopenia meningkat hingga 8 kali pada kehamilan dengan LES.

Anemia yang terjadi akibat proses keguguran, memerlukan tindakan transfusi. Angka kebutuhan akan transfusi darah pada penderita LES meningkat hingga 3 kali. ${ }^{10}$ LES juga merupakan salah satu penyebab tersering terjadinya warm autoimmune hemolytic anemia (WAIHA). ${ }^{11}$ Tindakan transfusi pada penderita autoimmune haemolytic anaemia (antara lain LES) memerlukan kehati-hatian ekstra. Beberapa tes kompatibilitas serologis perlu dilakukan sebelum transfusi ${ }^{11}$. Pada pasien ini, proses skrining darah menunjukkan adanya inkompatibilitas pada 20 kantung darah, sehinga pada beberapa pustaka menyarankan pemberian IVIG 24 jam sebelum transfusi, untuk mengatasi permasalahan inkompatibilitas. Meskipun masih menjadi kontroversi, pemberian IVIG dimaksudkan sebagai terapi imunosupresi karena mengandung antibodi yang bisa menahan kerusakan dan menetralkan auto-imun. ${ }^{10}$ Namun oleh karena mahalnya IVIG, menyebabkan pemberian IVIG pada pasien ini tidak dapat dilakukan.

Penanganan WAIHA melalui pemberian transfusi belum banyak diteliti. Studi yang tersedia saat ini hanya berupa penelitian retrospektif maupun studi kasus, sehingga epidemiologi penggunaanya belum banyak dipelajari. Tranfusi darah pada pasien dengan WAIHA baru diindikasikan apabila pasien menunjukkan gejala atau apabila kadar $\mathrm{Hb}<5$ g/dl. ${ }^{12}$ Pada pasien WAIHA, tranfusi dengan tingkat aglutinasi paling rendah (dalam hal ini $<3$ ), tetap memiliki risiko pada pasien ini. Proses transfusinya tetap dapat memicu terjadinya hemolisis, baik dalam level sedang bahkan berat. Namun berdasarkan beberapa penelitian 
sebelumnya menunjukkan bahwa transfusi sel darah merah dapat dilakukan tanpa menimbulkan reaksi transfusi hemolitik akibat auto-antibodi ataupun allo-antibodi. Literatur lain juga menyebutkan bahwa sekalipun terjadi peningkatan hemolysis paska tranfusi, masih terdapat sebagian sel darah merah yang dapat bertahan. ${ }^{11}$ Sebaliknya, pasien yang tidak diberikan transfusi atau mendapatkan penundaan transfusi, mengalami peningkatan resiko kematian.

Banyak rekomendasi tentang transfusi sel-sel darah merah pada penyakit autoimun hemolitik yang memerlukan penjelasan lebih lanjut, sehingga adanya serologis positif pada cross-matches tidaklah menjadi alasan penundaan pada tindakan transfusi. ${ }^{11}$ Untuk itu perlu dijelaskan dengan baik kepada keluarga pasien tentang segala risiko yang mungkin terjadi.

\section{KESIMPULAN}

Kehamilan pada penderita LES dapat membahayakan ibu dan bayinya, sehingga dapat menyebabkan keguguran ataupun kelahiran prematur. Pada kasus ini menampilkan seorang wanita penderita LES, hamil 4 minggu yang mengalami keguguran. Akibat proses tersebut, terjadi penurunan kadar hemoglobin, hingga membutuhkan transfusi. Adanya inkompatibilitas, membuat transfusi bukanlah pilihan yang mudah. Tetapi mengatasi kondisi ini dengan pemberian IVIG tidak dapat dilakukan karena keterbatasan ekonomi. Pemberian washed erithrocyte pada pasien ini, berjalan dengan baik, tanpa efek samping transfusi. Kerjasama yang baik dengan pasien dan keluarganya, sangat membantu untuk keberhasilan terapi.

\section{DAFTAR PUSTAKA}

1. Khairani N, Wiyati PS, A.W. Utomo. Karakteristik Kehamilan Dengan Lupus Eritematosus Sistemik di RSUP Dr. Kariadi Semarang. JKD. 2018;7(2): 1457

2. Sudoyo AW, Setiyohadi B, Alwi I, Simabrata M, Setiati S. Buku Ajar Penyakit Dalam Jilid III. In: Interna Publishing. 2014. p. (36):3331-3419

3. Jaya Kusuma A. Lupus Eritematosus Sistemik Pada Kehamilan. J Intern Med. 2007;8(2):170-5

4. Stojan G, Baer AN. Flares of systemic lupus erythematosus during pregnancy and the puerperium: Prevention, diagnosis and management. Expert Rev Clin Immunol. 2012;8(5):439-53

5. Jakobsen IM, Helmig RB, Stengaard-Pedersen K. Maternal and foetal outcomes in pregnant systemic lupus erythematosus patients: An incident cohort from a stable referral population followed during 1990-2010. Scand J Rheumatol. 2015;44(5):377-84

6. Lateef A, Petri M. Managing lupus patients during pregnancy. Best Pract Res Clin Rheumatol [Internet]. 2013;27(3):435-47. Available from: http://dx.doi.org/10.1016/j.berh.201 3.07.005

7. Clowse MEB, Jamison M, Myers E, James AH. A national study of the complications of lupus in pregnancy. Am J Obstet Gynecol. 2008;199(2):127.e1-127.e6

8. Lechner K, Jäger U. How I treat autoimmune hemolytic anemias in adults. Blood. 2010;116(11):1831-8

9. Yürek S, Mayer B, Lmahallawi MA, Pruss A, Salama A. Precautions surrounding blood transfusion in autoimmune haemolytic anaemias are overestimated. Blood Transfus. 2015;13(4):616-21 
10. Branch DW, Porter TF, Belfort MA, Paidas MJ, B. Gonik. Obstetric uses of intravenous immunoglobulin: Successes, failures, and promises. J Allergy Clin Immunol. 2001;108(4):S13

11. Salama A. Treatment options for primary autoimmune hemolityc anemia: a short comprehensive review. Transfus Med Hemother. 2015;42:294-301
12. Barros MMO, Jr DML. Autoimmune hemolytic anemia: transfusion challenges and solutions. Int J Clin Transfus Med. 2017;5:9-18 